\title{
INVESTIGATION OF THE IMPACT OF RAILWAYS ON HOUSING VALUES; THE CASE OF ISTANBUL, TURKEY
}

\author{
ELİF CAN CENGİZ ${ }^{1}$ \& HÜSEYİN MURAT ÇELİK ${ }^{1}$ \\ ${ }^{1}$ Istanbul Technical University, Turkey
}

\begin{abstract}
Housing units located near transportation facilities tend to have a higher market value than those that are at a greater distance to transport facilities but have similar characteristics. Provision of public infrastructure has a great impact on urban areas, especially on urban development patterns, spatial distribution of urban land use and real estate values. Mass transit systems are one of the most important public infrastructures in cities. Mass transit operations have a significant effect on property values, since they increase accessibility in urban areas. Railway projects are long-lasting investments and by their nature are extremely expensive when compared to other land transportation modes. It is not always possible or reasonable for many countries to fund these high-price projects only with their national budget generated by taxes collected from all citizens. Literature suggests that property values tend to rise in parallel to land values after any kind of public infrastructure investment. Nowadays transportation, especially railway system investments, is regarded as the most important public infrastructure in urban areas impacting land values maximally. Railway investments are becoming widespread in Turkey, especially in Istanbul as Istanbul is the most important and most populated city in country. As due to their high operation costs urban public transport systems, especially railway systems, rarely make a profit, private investors are not willing to get involved in these projects. Furthermore, it is not possible to finance all rail system investments from public funds. This article aims to prove the impact of railway systems on housing values and investigate the possibility of internalizing this increased value for financing railway investments. The main objective of this article is to calculate the impact of distance to a railway station on the value of properties by using the hedonic price model on an existing railway corridor and applying this anticipated impact on a proposed railway corridor. Finally, the calculated value is used as a preliminary basis as a funding model for railway projects in developing countries like Turkey.

Keywords: hedonic price model, housing values, metro investment, public transport, railway funding.
\end{abstract}

\section{INTRODUCTION}

The concern of economists about urban rent values dates back to $18^{\text {th }}$ century. Today's urban land value theories are derived from Von Thünen's location differential rent theory [1]. As a successor of Von Thünen; Alonso developed the bid rent theory which states that rents tend to increase close to the city center as individuals wish to minimize daily transportation costs [2]. Nowadays, unlike their historical counterparts, cities have more than one center. These centers are formed by transportation networks. In the past, cities had one market place where all economic activities took place. Thus being close to the central business district (CBD) was an important determinant for housing prices. After transportation became easily accessible throughout the city, transportation access points which connect the CBD with locations at greater distances became new attraction points. Thus, property prices increased around such transportation access points as these meant less mobility time and cost [3].

Housing units at closer distance to public transportation networks mostly tend to demand higher market values than those with similar characteristics but at a further distance. Such differentiation is due to the savings in transportation costs [4].

Provision of public infrastructure has a deep influence on urban areas, especially on urban development patterns and spatial distribution of urban land use and real estate values [5].

Mass transit systems are one of the most important public infrastructures in cities. Mass transit operations have a significant impact on property values as they increase accessibility 
in urban areas. Based on a survey conducted by Zhang et al., 2014, when different mass transit systems are compared, the metro system adds the highest premium on housing prices, light rail transit (LRT) has a moderate and bus rapid transit (BRT) has the lowest premium [6].

Rail systems have fixed infrastructures which lead to permanent and radical changes in urban areas. These fixed infrastructures also make rail transit investments extremely expensive [7].

The demand for high quality and efficient transport networks in cities and the related infrastructure is increasing throughout the world. Despite the increasing demand, the supply is insufficient. This creates a continuous gap between supply and demand. Because of issues like limited investment funds, unpredictable revenues, political interventions and lack of technical know-how, in short various kinds of resource limitations, economies do not always have the capability to minimize this gap [8].

The impact of proximity to a railway station is an issue frequently discussed. There are studies claiming that being close to a railway station has a positive impact on real estate prices. This is basically demonstrated via accessibility which provides considerable time and cost savings to the transit users, as it reduces their need to use their private car and other means of road transportation [9-11].

In this study, first the positive impact of an existing railway corridor on housing prices in Istanbul is calculated, then this calculated value is reflected on a proposed railway project which is under construction currently and then the anticipated total increase in housing prices is calculated. The main intention of this study is to demonstrate the calculations reflecting the impact of transport investments on land values and to propose a kind of preliminary baseline in using these figures in potential railway financing. In short, the asserted problem and its potential solution are investigated together. The indicated problem mainly refers to the limited funding resources for railway projects and the potential refers to the increasing land values through transport investments.

In theory, the most basic concept for transport financing is that 'those who enjoy the benefits of transport improvements should bear the corresponding costs'. Since it is very difficult to identify benefits derived from any transport investment, it is important to simplify the method [12]. During this study, benefits are estimated by determining the change of real estate value by using the hedonic price model. The model is developed on an existing railway corridor, and then the calculated value of the impact of the railway on housing prices is applied on a proposed railway project.

In the transportation market, when new roadways/railways are implemented, the value of the surrounding land increases, but without special funding systems being in place the landowners will be reluctant to contribute to the investment cost of the projects [12].

Turkey has a growing economy and thus needs investments in every sector across the country. All these projects, so-called mega projects, are in macro-scale and extremely expensive. As a general policy of the current government, both national and international private investors are encouraged to get involved in these mega projects. Public sector utilizes the private sector's know-how and funds. In Turkey, the public sector stands only as a controller and monitoring mechanism in public private partnership (PPP) projects.

In Turkey, such PPP projects generally use the built operate transfer (BOT) model. The private sector construct operates for a given period of time and transfers the property to the public sector after the operation period comes to an end. However, economic instability does not attract private investors, especially foreign investors to undertake mega projects in 
this country. Thus, in order to encourage the private sector, the government gives generous guarantees to them. All these BOT projects in Turkey are planned on the basis of operation revenue. If they do not generate sufficient revenue for the investor, the government gives a guarantee to meet the difference between the actual and the expected revenue. By developing a new model for railway financing, this study investigates the possibility of relieving the government from having to provide major guarantees to investors for the realization of these projects. This new model includes the value capture which is created by railway projects.

\subsection{Case Study Area and Introduction}

With its 15 million inhabitants Istanbul is the most populated city in Turkey. It is also regarded as the economic center of the country. This high population and economic activity results in high mobility needs. There is a diversified modal split in the city which includes sea, rail and road transportation [13] (see Fig. 1).

There are 27 different rail lines in Istanbul including many kinds of the rail modes. The total length of the rail network in Istanbul is $215.15 \mathrm{~km}$ (in 2018). Considering its linear urban macroform, this is not sufficient. Only central areas can utilize railway transportation. Peripheral areas depend mostly on road transport modes like buses and minibuses. After 2004, the railway network has been improved. The total route length has increased from $45.10 \mathrm{~km}$ to $170.05 \mathrm{~km}$. Despite high investment costs and long construction periods, railway investments in Istanbul continue at an increasing rate. The aim is that in 2023 the total railway network will reach $624.65 \mathrm{~km}$ [14].

By 2019, new railway lines of $322.41 \mathrm{~km}$ length will be constructed in Istanbul. There are projects that are due to complete in 2023. After these projects are completed, the total railway network in Istanbul will be $1.100 \mathrm{~km}$ [10] (Nakagawa \& Matsunaka, 2006). There are more than 60 railway projects planned or ongoing in Istanbul today. In this study, the Atakoy-Ikitelli metro line is examined. This corridor of $13 \mathrm{~km}$ route length will have 12 stations

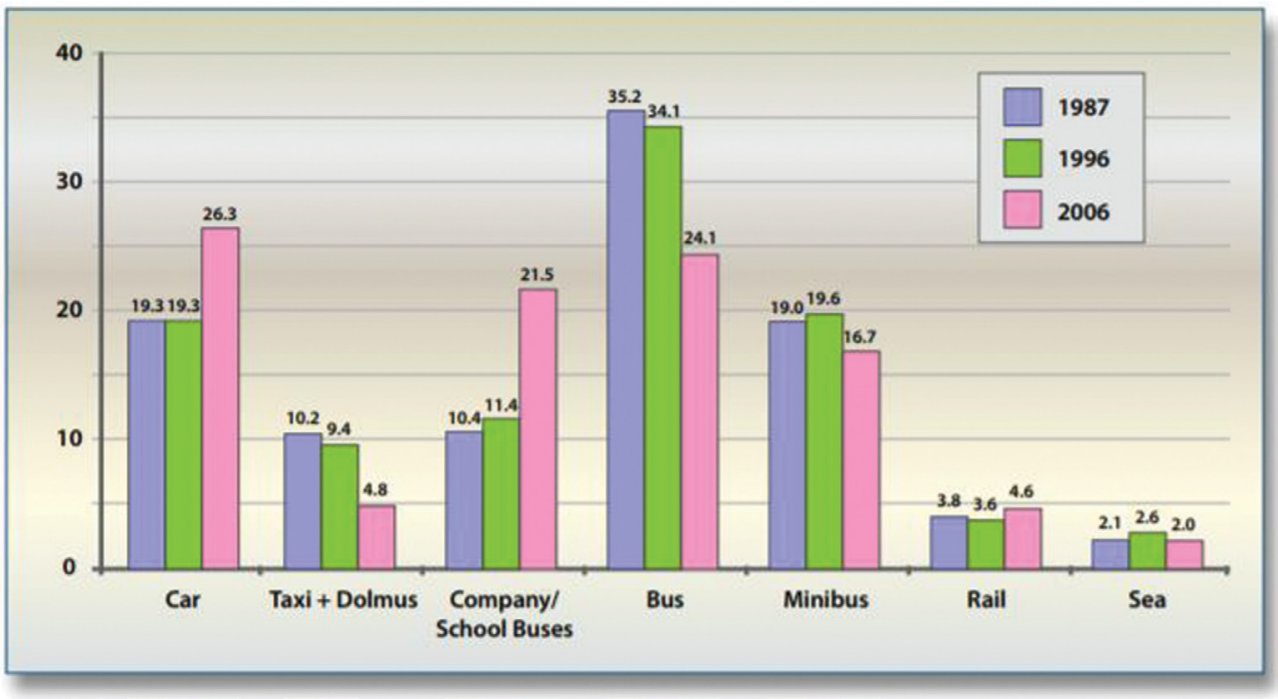

Figure 1: Modal split in Istanbul. 
with. After it is completed, it will serve one of the most important corridors on the European side of the city. This article is designed as a comparative study; thus a further railway corridor is selected. The new corridor should have similar socio-economic and housing stock characteristics and needs to be close in location to the main case study area, namely the AtakoyBasınekspres-İkitelli metro line. Different from the Atakoy-Basınekspres-İkitelli metro line that is under construction currently, this new case study area should have an operating railway system so that it will allow estimation with regard to the impact of railway on housing values. As control case, the Esenler-Kirazli metro line is selected. This is an extension of a metro line on the European side. It has five stations and has $5.8 \mathrm{~km}$ route length [15].

\section{METHODOLOGY}

As suggested in various studies, the distance from a transport infrastructure is one of the most important variables that affect housing prices. According to the Turkish Zoning Law, $500 \mathrm{~m}$ is regarded as the reasonable walking distance. Thus, real estate data for this study is collected within a 500-m radius from stations [16]. See Fig. 2 as data flow diagram describing the methodology.

The primary aim of this study is to calculate the impact of metro stations on property values of properties in the surrounding area within a 500-m radius. The impact of proximity to metro stations is calculated by using the hedonic price model. Hedonic price model allows to calculate the impact of every self-existing attributes of an apartment on its value [17]. Table 1 shows the attributes that are commonly used in the hedonic pricing model and that are also used in this study.

The construction of the main case project has just commenced. Thus, at present, there is no operating station that can be used in the model. In order to calculate the impact of the rail system station on surrounding property values, a second railway corridor is selected to develop the hedonic pricing model which is an extension railway corridor called Esenler-Kirazli metro line, hereinafter referred to as 'control case'. Those two case studies were selected because they are very close to each other location-wise. Both corridors have similar features such as land use around the stations and housing stock, and they have similar socio-economic, cultural and income-related features [16]. Selected two case studies can be seen in the Figure 3.

Literature Review \& Questionnaire design

Conducting on site questionnaire with real estate agents in control case

Data digitization \& model run with R-Studio Program in the control case

Obtaining total number of individual housing units around stations in main case

Applying obtained distance coefficent from the model to the main case

Calculation of total value increse and designing betterment tax collection methodology

Figure 2: Data flow diagram for methodology. 
Table 1: Definition of variables used in the model.

\begin{tabular}{ll}
\hline Variable definition & Variable name \\
\hline $\begin{array}{l}\text { Distance of the housing unit to the nearest metro station (in meters) } \\
\text { Floor area of the housing unit (in square meters) }\end{array}$ & $\begin{array}{l}\text { distance } \\
\text { size }\end{array}$ \\
$\begin{array}{l}\text { Price of property (selling price of the housing unit in Turkish Lira) } \\
\text { price } \\
\text { Age of building (years) }\end{array}$ & $\begin{array}{l}\text { age } \\
\text { rooms }\end{array}$ \\
$\begin{array}{l}\text { Number of rooms in the housing unit } \\
\text { bumber of bathrooms in the housing unit }\end{array}$ & $\begin{array}{l}\text { alaturka } \\
\text { aummy variable asserting the kind of toilet in the housing unit, }\end{array}$ \\
$\begin{array}{l}\text { Dummy variable indicating whether the building is located at a corner } \\
\text { or not (1: if located at a corner, 0: otherwise). }\end{array}$ & corner \\
$\begin{array}{l}\text { Dummy variable indicating whether the housing unit has a west facade } \\
\text { or not (1: if located facing west, 0: otherwise). }\end{array}$ & west \\
$\begin{array}{l}\text { Dummy variable indicating whether the housing unit has a North } \\
\text { facade or not (1: if located facing north, 0: otherwise). }\end{array}$ & north \\
$\begin{array}{l}\text { Dummy variable indicating whether the housing unit has a South } \\
\text { facade or not (1: if located facing south, 0: otherwise) } \\
\begin{array}{l}\text { Dummy variable asserting whether there is an elevator in the building } \\
\text { or not (1: if there is elevator, 0: otherwise). }\end{array}\end{array}$ & south \\
\hline
\end{tabular}

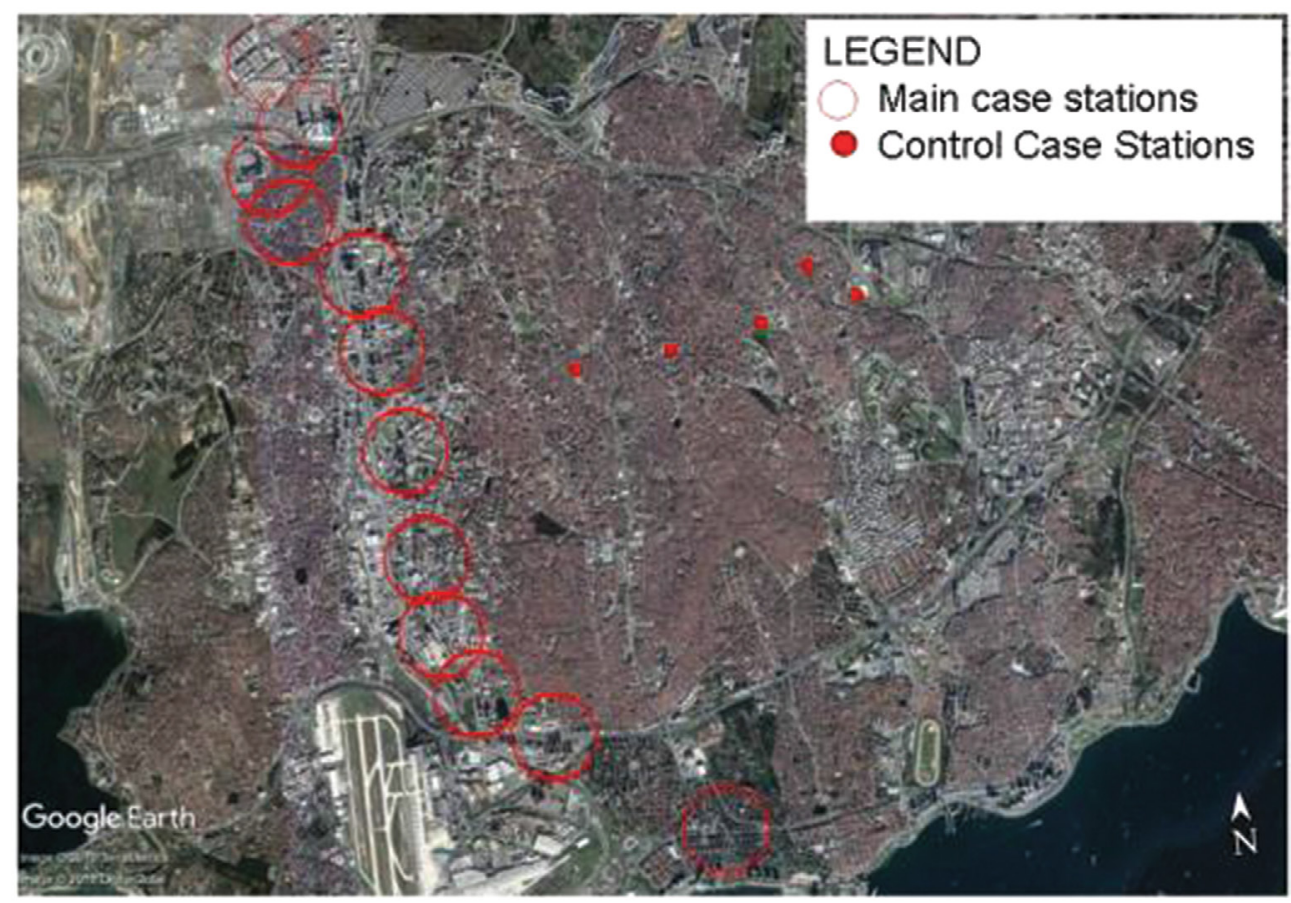

Figure 3: Two case studies together [18]. 
In order to calculate the value impact of proximity to railway stations, a questionnaire survey is conducted with rail estate agents working with 4-5 students on the site around the stations. On-site survey was started on 1 April 2017 and lasted for 1 week. Detailed information on housing prices and their attributes are collected in the control case which has five stations. A number of 665 questionnaires are collected in total around these five stations. After the model is developed, the impact of being $1 \mathrm{~m}$ closer to a station is calculated, and the obtained coefficient is used for the main case study [16].

In this part of the study, the hedonic price model is run for the control case. The impact of each and every attribute on the housing price is calculated using the data gathered via questionnaires. The study continues with detailed discussions on the first model. The Google Earth program is used to obtain the distance between housing units and stations. The distance used in the model is air distance; the reason for using air distance instead of walking distance is the calculation methodology for the anticipated value increase on the main case.

\section{MODEL RESULTS}

After questionnaires digitized to excel sheet, model is run with R-Studio program by defining every variable in order to obtain an equation. Price of the apartment is the dependent variable to the other features of it. Table 2 shows the model results obtained from the related program.

Table 2: Model results.

\begin{tabular}{|c|c|c|c|c|c|c|c|}
\hline Source & SS & $d f$ & MS & \multirow{2}{*}{\multicolumn{2}{|c|}{$\begin{array}{l}\text { Number of obs } \\
\text { F(11, 653) } \\
\text { Prob > F }\end{array}$}} & \multicolumn{2}{|l|}{665} \\
\hline Model & $1.8575 e+12$ & 11 & $1.6886 e+11$ & & & 0.0000 & \\
\hline Residual & $1.3822 \mathrm{e}+12$ & 653 & $2.1168 \mathrm{e}+09$ & \multicolumn{2}{|c|}{ R-squared } & 0.5733 & \\
\hline & & & & \multirow{2}{*}{\multicolumn{2}{|c|}{$\begin{array}{l}\text { Adj R-squared } \\
\text { Root MSE }\end{array}$}} & 0.5662 & \\
\hline Total & $3.2397 e+12$ & 664 & $4.8791 e+09$ & & & 46008 & \\
\hline Price_new & Coef. & & td. Err. & $t$ & P>ItI & \multicolumn{2}{|c|}{ [95\% Conf. Interval] } \\
\hline air distance & -53.84791 & & 19.80832 & -2.72 & 0.007 & -92.74359 & -14.95222 \\
\hline age & $-3,856.095$ & & 241.4267 & -15.97 & 0.000 & $-4,330.161$ & $-3,382.029$ \\
\hline size & 612.0502 & & 158.6117 & 3.86 & 0.000 & $8,559.484$ & 923.5007 \\
\hline rooms & $18,641.78$ & & 134.587 & 3.63 & 0.000 & $8,559.4840$ & $28,724.07$ \\
\hline baths & $23,672.19$ & & 665.66 & 3.55 & 0.000 & $10,583.47$ & $36,760.9$ \\
\hline alaturka & $14,625.76$ & & 799.835 & 3.05 & 0.002 & $5,200.786$ & $24,050.73$ \\
\hline corner & $-25,102.66$ & 10,8 & 315.1 & -2.32 & 0.021 & $-46,339.24$ & $-3,866.091$ \\
\hline south & $-22,210.63$ & 10,4 & 416.01 & -2.13 & 0.033 & $-42,663.55$ & $-1,757.709$ \\
\hline west & $-20,810.5$ & 11,3 & 364.87 & -1.83 & 0.068 & $-43,126.59$ & $1,505.596$ \\
\hline north & $-19,716.2$ & 14,0 & 65.37 & -1.40 & 0.161 & $-47,335.01$ & $7,902.614$ \\
\hline elevator & $22,008.68$ & & 315.631 & 4.57 & 0.000 & $12,552.69$ & $31,464.67$ \\
\hline _cons & 167,938 & 14,6 & 697 & 11.43 & 0.000 & $139,078.8$ & $196,797.1$ \\
\hline
\end{tabular}

X1: air distance, X2: age, X3: size, X4: rooms X5: bathrooms, X6: alaturka, X7: corner, X8: south, X9: west, X10: north, X11: elevator. 
To begin with, according to the calculated $t$-test values asserted above, almost all the exploratory variables exhibit statistically significant coefficients, except for $X 9$ (west or not) and $X 10$ (north or not). Second, according to the calculated $F$-test, the model is statistically significant. In other words, the theoretical investigation which refers to the hedonic pricing model of the related housing units seems statistically meaningful. Third, the calculation of the coefficient of determination $\left(R^{\wedge} 2\right)$, which is equal to 0.5733 and is a kind of acceptable value for such an exploratory investigation, asserts that the stated independent variables in modeling housing prices are able to statistically explain the related price changes around 56.62 percentage level [16].

Besides the $t$-test values, the coefficients for variables seem significant. As distance and housing value have an inverse ratio, the coefficient for air distance carries a negative value. That means, as the distance from the station increases, the price of apartments decrease. Similar to distance, age also carries negative value. As apartments get older their price decreases. As the size of the apartments increases, the price also increases; in other words, bigger apartments are more expensive. Number of bathrooms, existence of an alaturka toilette and elevator also increase the price. But it is surprising that the facade of the apartment does not have a positive impact on the price, especially as according to literature corner apartments are always more expensive than others since they have a dual facade. But in this data set, it has a negative impact. This can only be explained by the cultural characteristics of the neighborhood. Most of the buildings in the area are old and very close to each other. This may influence users' preferences as for privacy reasons they may not wish to be too close to other buildings. Finally, the equation for an apartment depending on all its attributes is as follows;

$$
P=167,938-53.84 \times \mathrm{X} 1-3,856.09 \times \mathrm{X} 2+612.05 \times \mathrm{X} 3+18,641 \times \mathrm{X} 4+23,672 \times \mathrm{X} 5+14,625.7
$$

$6 \times X 6-25,102.66 \times X 7-22,210.63 \times X 8--20,810.5 \times X 9-19,716.2 * X 10+22,008.68 \times X 11$

In the second part of the study, the calculated coefficient for distance in the control case is used to calculate the total value increase in the main case. The methodology for this is obtaining the total number of single housing units served by each station.

\section{DISCUSSION}

The positive impact of railway investments on the housing market is demonstrated with the help of literature and the use of two case studies in Istanbul. As a further research, a new model will be developed to collect some part of this increased value from property owners for the financing of the railway. Since his kinds of urban infrastructure projects are mainly financed by governmental funds, some parts should turn to national budget in order to maintain the further investment funds. In the "Conclusion" section, the betterment tax collection methodology will be discussed as a new financial instrument.

\section{CONCLUSION}

Based on the model, being located $1 \mathrm{~m}$ closer to the railway station increases the property value by $53.84 \mathrm{TL}$. The model is developed for the properties within a 500-m radius from the stations. Thus, this area is divided into zones of 100-m range see Fig. 5. The number of individual housing units is established within these zones. The average distance for each zone is accepted as follows:

$1-100 \mathrm{~m}--------50 \mathrm{~m}$
$100-200 \mathrm{~m}-----150 \mathrm{~m}$
$200-300 \mathrm{~m}-----250 \mathrm{~m}$
$300-400 \mathrm{~m}------350 \mathrm{~m}$
$400-500 \mathrm{~m}------450 \mathrm{~m}$




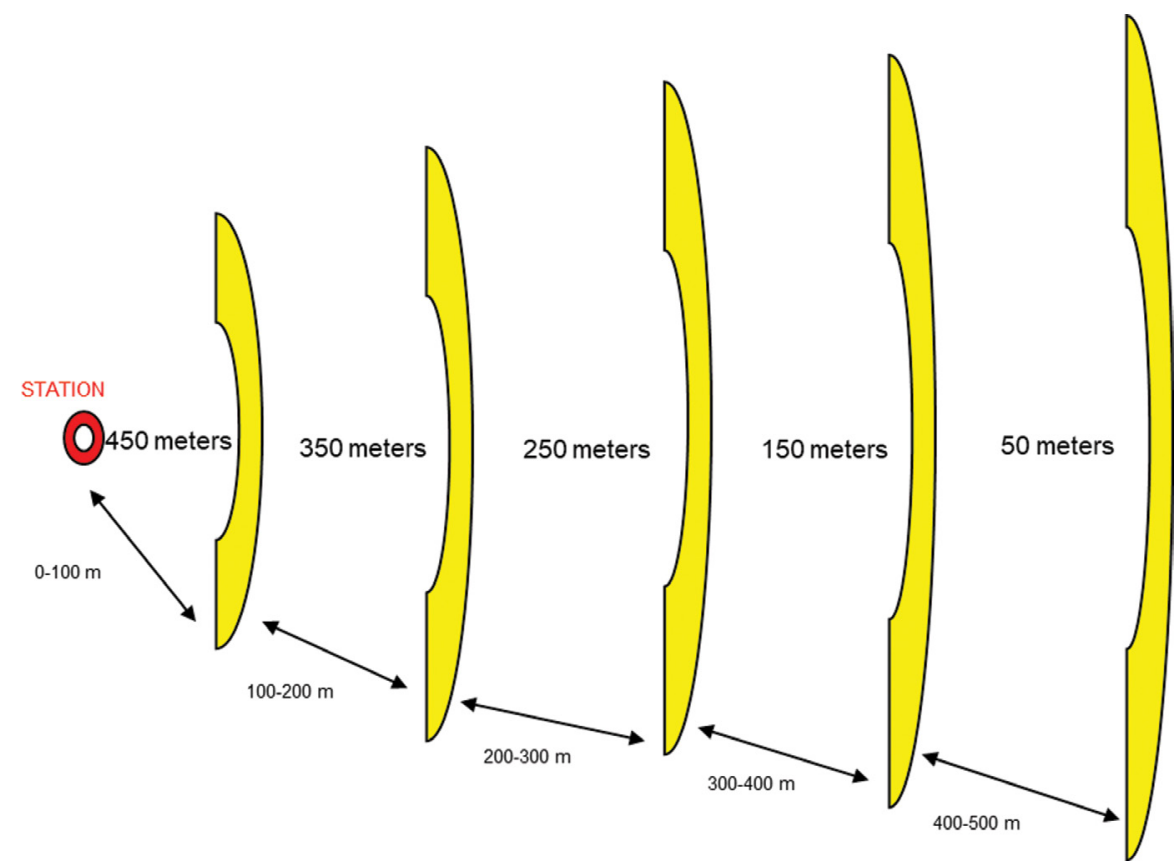

Figure 4: Inverse ratio between average distance of zones and the value increase.

Based on this assumption, the average value increase for each zone is calculated, and the numbers of individual housing units around each station and in each zone are obtained by using the 'Google Earth' program and Google Maps' Street View feature. The street view feature of 'Google maps' allows us to see the number of floors of the buildings (see Fig. 4) and the number of apartments in one floor is obtained by conducting site visits and the declarations of real estate agents.

In Fig. 4, the inverse ratio between distance and value increases. The further the housing unit is from the metro station the lower the value increase rate becomes.

There is an inverse ratio between distance and value increase. For instance, if a housing unit is located in the $0-100 \mathrm{~m}$ zone the value increase will be as follows as per Turkish Lira (TL). Fig. 6 shows the average anticipated value increase for each zone.

$450 \mathrm{~m} \times 53.84=24.228 \mathrm{TL}$

Similarly, if a housing unit exists in the $400-500 \mathrm{~m}$ zone, the value increase will be:

$50 \mathrm{~m} \times 53.84=2.692 \mathrm{TL}$

Table 3 shows the total number of individual housing units along the corridor at the 11 stations in a 100-m range. In Table 4, the anticipated average value increase is applied to the number of housing units.

As it is seen in the Table 4, the total amount of value increase is not such that can be ignored, especially when the capital cost for the metro project is considered. The price proposal of the party who won the bid was 338 million Euro, at that time the Euro exchange rate was 3.29. Today. the calculated value increase is over one billion TL, which is approximately 164 million Euro with the Euro exchange rate of 6.09 TL [19]. 


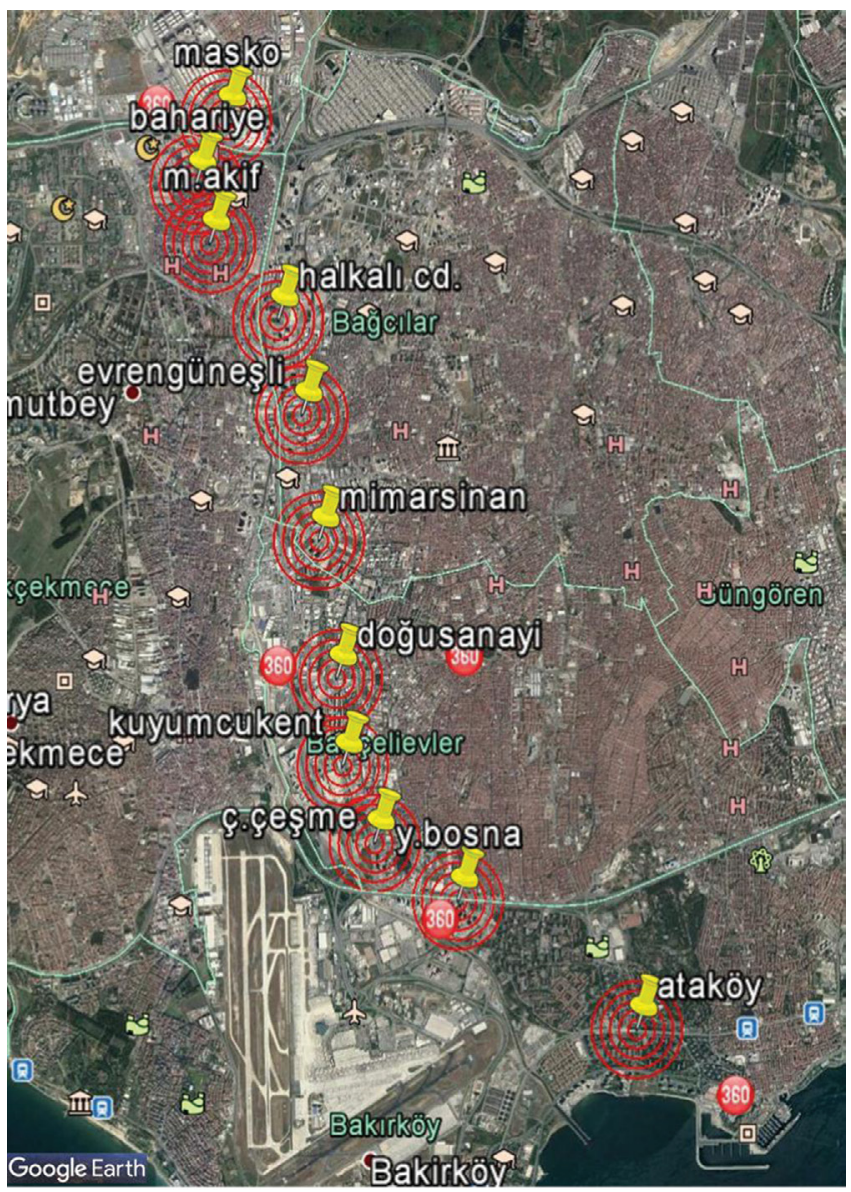

Figure 5: All stations within a 100-m radius circle [18].

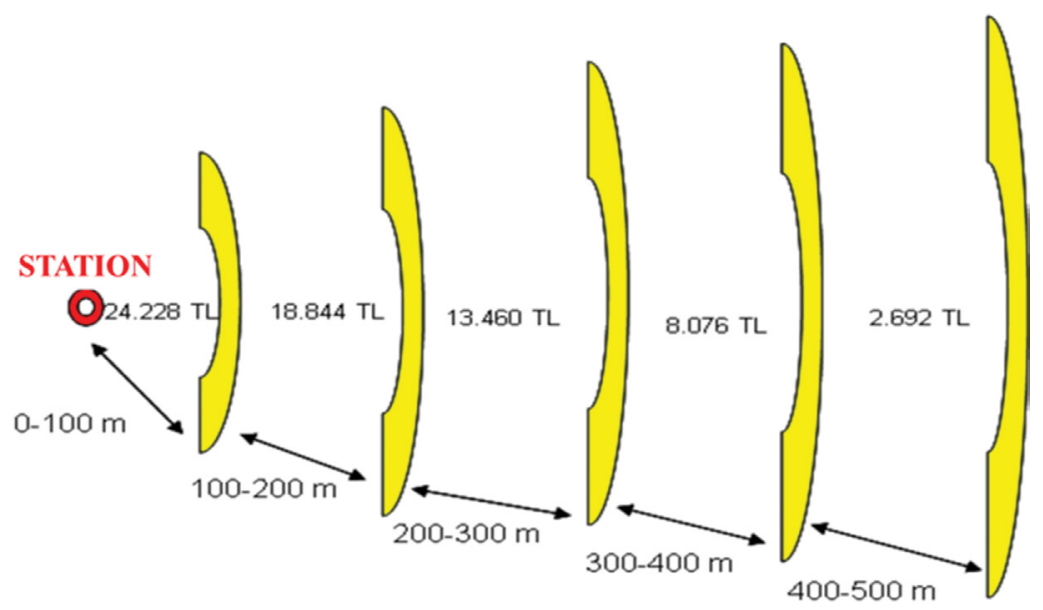

Figure 6: Average anticipated value increase for each zone. 
Table 3: Total number of individual housing units for all stations in the main case.

\begin{tabular}{lccccc}
\hline Station name & $\begin{array}{c}0-100 \\
\text { Number of } \\
\text { houses }\end{array}$ & $\begin{array}{c}100-200 \\
\text { Number of } \\
\text { houses }\end{array}$ & $\begin{array}{c}200-300 \\
\text { Number of } \\
\text { houses }\end{array}$ & $\begin{array}{c}300-400 \\
\text { Number of } \\
\text { houses }\end{array}$ & $\begin{array}{c}\text { 400-500 } \\
\text { Number of } \\
\text { houses }\end{array}$ \\
\hline Atakoy & 192 & 1,152 & 1,824 & 3,424 & 3,360 \\
Yenibosna & 541 & 1,109 & 501 & 2,137 & 3,323 \\
Çobançeşme & 0 & 0 & 585 & 600 & 1,000 \\
Kuyumcukent & 0 & 0 & 120 & 736 & 1,001 \\
Doğu Sanayi & 0 & 238 & 370 & 1,895 & 1,270 \\
Mimarsinan & 282 & 0 & 0 & 916 & 960 \\
Evrengüneşli & 256 & 1,168 & 1,488 & 3,086 & 6,029 \\
Halkalı Cd. & 230 & 1,267 & 0 & 607 & 900 \\
Bahariye & 1,456 & 4,096 & 9,252 & 4,544 & 4,256 \\
Mehmet Akif & 1,408 & 5,104 & 7,952 & 10,976 & 8,848 \\
Masko & 0 & 0 & 1,081 & 0 & 0 \\
\hline
\end{tabular}

Table 4: Total calculated value increase (Turkish Lira).

\begin{tabular}{|c|c|c|c|c|c|c|}
\hline \multirow{2}{*}{$\begin{array}{l}\text { STATION } \\
\text { NAME } \\
\text { Atakoy }\end{array}$} & \multicolumn{6}{|c|}{ TOTAL VALUE INCREASE (Turkish Lira) } \\
\hline & $4,652,640$ & $21,712,320$ & $24,555,600$ & $27,657,360$ & $9,046,800$ & $87,624,720$ \\
\hline Yenibosna & $13,109,783$ & $20,901,878$ & $6,744,713$ & $17,261,618$ & $8,947,178$ & $66,965,168$ \\
\hline Çobançeşme & 0 & 0 & $7,875,563$ & $4,846,500$ & $2,692,500$ & $15,414,563$ \\
\hline Kuyumcukent & 0 & 0 & $1,615,500$ & $5,945,040$ & $2,695,193$ & $10,255,733$ \\
\hline Doğu Sanayi & 0 & $4,485,705$ & $4,981,125$ & $15,306,863$ & $3,419,475$ & $28,193,168$ \\
\hline Mimarsinan & $6,833,565$ & 0 & 0 & $7,398,990$ & $2,584,800$ & $16,817,355$ \\
\hline Evrengüneşli & $6,203,520$ & $22,013,880$ & $20,032,200$ & $24,927,165$ & $16,233,083$ & $89,409,848$ \\
\hline Halkalı Cd. & $5,573,475$ & $23,879,783$ & 0 & $4,903,043$ & $2,423,250$ & $36,779,550$ \\
\hline Mehmet Akif & $34,119,360$ & $96,197,640$ & $107,053,800$ & $88,658,640$ & $23,823,240$ & $349,852,680$ \\
\hline Bahariye & $35,282,520$ & $77,199,360$ & $124,555,050$ & $36,704,160$ & $11,459,280$ & $285,200,370$ \\
\hline \multirow[t]{2}{*}{ Masko } & 0 & 0 & $14,552,963$ & 0 & 0 & $14,552,963$ \\
\hline & \multicolumn{5}{|c|}{ TOTAL (Turkish Lira) } & $1,001,066,118$ \\
\hline
\end{tabular}

\section{REFERENCES}

[1] Thünen, J. H., Isolated State, Pergamon Press: New York, 1966.

[2] Alonso, W., Location and Land Use. Toward a General Theory of Land Rent, Harward University Press: Cambridge, 1964.

[3] Debrezion, G., Pels, E. \& Rietveld, P., The impact of rail transport on real estate prices: An emrical analysis of the dutch housing market. URban Studies, pp. 1-19, 2010 
[4] Agostini, C. A. \& Palmucci, G., The anticipated capitalization effect of a new metro line on housing prices. Fiscal Studies, pp. 233-256, 2008.

[5] Damm, D., Lerman, S. R., Lerner-Lam, E. \& Young, J., Response of urban real estate values in anticipation of the Washington metro. Journal of Transport Economics and Policy, pp. 315-336, 1980.

[6] Zhang, X., Liu, X., Hang, J., Yao, D. \& Shi, G. Do urban rail transit facilities affect housing prices? Evidence from China. Sustainability, 2016.

[7] Özgür, Ö., An Analysis of Urban Rail Transit Investments, Middle East Technical University: Ankara, 2009.

[8] Jain, P. \& Cullinane, S. Avenues for transport infrastructure finance in Hong Kong: Public private financing initiatives. International Conference on Traffic and TRansportation Studies, ASCE Library: Guilin, 2002.

[9] Hewit, C. M., Hewit, M. A. \& Hewit, W. E., The effect of proximity to urban rail on housing prices in Ottawa. Journal of Public Transportation, pp. 43-65, 2012.

[10] Harjunan, O., Metro Investment and the Housing Market Anticipation Effect, City of Helsinki, Executive Office, Urban Research and Statistics: Helsinki, Finland, 2018.

[11] Gallo, M., The impact of urban transit systems on property values: a model and some evidences from the city of Naples. (D. F. Llorca, Ed.). Journal of Advanced Transportation, 2018.

[12] Nakagawa, D. \& Matsunaka, R. Transport Policy and Funding, Elsevier, 2006.

[13] Henning, M., Sustainable Urban Mobility: The Example of Istanbul, GIZ Transport Policy Advisory Services: Eschborn, 2011.

[14] İstanbulunMetrosu., Ístanbulun Metrosu. on 12 01, 2018 İstanbulun Metrosu: available at http://www.istanbulunmetrosu.com/?Lang=tr-TR, 2018.

[15] Metroİstanbul., Metro İstanbul. on 12 17, 2018 Metro İstanbul: available at https:// www.metro.istanbul/Hatlarimiz/ProjeHalindekiHatlar?projeInsaat=0\&q=14, 2018.

[16] Cengiz, E.C. \& Çelik, H.M., Financing Railway via Urban Development. 24th International Conference on Urban Development and Environment (s. 209-2018), WIT Press: Seville, 2019.

[17] Rosen, S., Hedonic prices and implicit markets: Product differentiation in pure competition. Journal of Political Economy, 82(1), pp. 34-55, 1974.

[18] GoogleEarth, Google Earth. on 12 17, 2018 retriewed from Google Earth, 2018.

[19] TCMB, Turkish Central Bank. on 12 17, 2018 Turkish Central Bank: available at https://www.tcmb.gov.tr/, 2018. 